\title{
ELEKTROS ENERGIJOS RINKOS KAINOS SAVYBIŲ TYRIMAS: LIETUVOS ATVEJIS
}

\author{
Viktorija Bobinaite் $\dot{1}^{1}$ Aldona Juozapavičiené⿱ \\ ${ }^{1}$ Lietuvos energetikos institutas, Breslaujos g. 3, LT-44403 Kaunas, Lietuva \\ ${ }^{1,2}$ Kauno technologijos universitetas, Laisvès al. 55, LT-44309 Kaunas, Lietuva \\ El.paštas: ${ }^{1}$ viktorija@mail.lei.lt; ${ }^{2}$ aldona.juozapaviciene@ktu.lt \\ Iteikta 2011-11-26; priimta 2012-02-26
}

\begin{abstract}
Santrauka. Straipsnyje apibendrinama pasaulinè patirtis ir susisteminama mokslinè literatūra elektros energijos rinkos kainos savybių problematika, pasiūlomi kainos savybių vertinimo rodikliai, atliekamas biržos kainos savybių tyrimas Lietuvos pavyzdžiu. Tikslui pasiekti taikomi du metodai - mokslinès literatūros sisteminimo ir statistinès analizès. Teorinejje darbo dalyje išskiriamos pagrindinès elektros energijos rinkos kainos savybės ir veiksniai, darantys ịtakos savybių pasireiškimui. Metodinèje darbo dalyje pasiūlomi rodikliai, sudarantys galimybę įvertinti kainos kaitumą ir kainų smailių pasireiškimą. Atlikus empirinį tyrimą nustatyta, kad Lietuvoje elektros energijos kaina buvo kaiti. Žiemos laikotarpiu, kai prekybą rinkoje vykdè šiluminès elektrinès, kainos kaitumas mažèjo, tačiau vidutine kaina didejo. Pavasarị, esant galimybei importuoti elektros energiją pigiau, kainos kaitumas didejo, o vidutinè kaina mažejo. Kaičiausia ir didžiausia kaina buvo vasarą (variacijos koeficientas - 19,74 proc., standartinis nuokrypis - 32,50 LTL/MWh, vidutinis kainų lygis - 164,60 LTL/MWh), kurios metu dažniausiai susiformuodavo kainų smailès. Jos truko 2,64 proc. viso 2010-2011 m. rugsèjo mèn. laiko.
\end{abstract}

Reikšminiai žodžiai: elektros energija, didmeninė rinka, kaina, aprašomoji statistika, kaitumas, kainų smailè.

\section{ANALYSIS OF FEATURES OF POWER MARKET PRICE: LITHUANIAN CASE}

\author{
Viktorija Bobinaité丶 ${ }^{1}$ Aldona Juozapavičiené⿱ \\ ${ }^{1}$ Lithuanian Energy Institute, Breslaujos g. 3, LT-44403 Kaunas, Lithuania \\ ${ }^{1,2}$ Kaunas University of Technology, Laisves al. 55, LT-44309 Kaunas, Lithuania \\ E-mails: ${ }^{1}$ viktorija@mail.lei.lt (corresponding author); ${ }^{2}$ aldona.juozapaviciene@ktu.lt
}

Received 26 November 2011; accepted 26 February 2012

\begin{abstract}
Generalized world experience and summary of scientific literature on the issue of power market price features have been presented in the paper; indicators for evaluation of these features have been offered as well and the analysis of price characteristics in Lithuanian power exchange has been performed. The following methods have been employed - scientific literature analysis and generalization and statistical analysis methods. The main features of power market price and factors influencing them have been determined in the theoretical part of the paper. Indicators which enable to evaluate the features of power market price have been proposed in the methodological part of the paper. The analysis has shown that power market price was volatile in Lithuania. In winter when thermal power plants operated in the market, power market price tended to increase, but its volatility decreased. In spring, when cheap import was available, power market price tended to reduce, but its volatility increased. Power market price was the most volatile and highest in summer. During this season price spikes often formed. Price spikes in summer took $2.64 \%$ of all time analyzed.
\end{abstract}

Keywords: electricity (power), wholesale market, price, descriptive statistics, volatility, price spike.

JEL Classification: C10, L94, Q40. 


\section{Ivadas}

Temos aktualumas ir problemos. Nuo XX a. devintojo dešimtmečio daugelis išsivysčiusių, pereinamojo tipo ir besivystančių pasaulio šalių pradejjo reformuoti elektros energetikos sektorius. Sektoriaus reformavimo modelis apemè ne tik ịstatymų leidybą, reguliavimo sistemos sukūrimą, pirmujų nepriklausomų gamintojų steigimą, restruktūrizavimą, privatizavimą, bet ir konkurencijos principų i̇diegimą (Nagayama 2007). Konkurencijos principų igyvendinimas reiškè perėjimą nuo visiško sektoriaus veiklų reguliavimo prie konkurencinių didmeninių ir mažmeninių elektros energijos rinkų kūrimo. Pagrindiniu tokių elektros energijos rinkų parametru tapo kaina, kuri šiandienèmis sąlygomis turi daug savybių. Jų identifikavimas tampa tikru iššūkiu asmenims, siekiantiems tam tikru tikslumu numatyti kainos kitimo tendencijas ateityje ir priimti pagrịstus bei racionalius ūkio valdymo sprendimus. Šiuo metu dèl pačios elektros energijos rinkos jaunumo ir analizių stokos kainos savybès dar nèra iki galo suprastos ir pažintos, todèl papildomi tyrimai šioje srityje yra aktualūs.

Darbo naujumas. Siekiant ịvertinti elektros energijos kainos savybes, parengiama kainos savybių vertinimo rodiklių sistema. Ja remiantis elektros energijos rinkos kainos savybès tiriamos Lietuvos pavyzdžiu.

Darbo objektas - elektros energijos rinkos kaina.

Darbo tikslas - apibendrinus pasaulinę patirtị ir susisteminus mokslinę literatūrą elektros energijos rinkos kainos savybių problematika, pasiūlyti kainos savybių vertinimo rodiklius ir atlikti kainos savybių tyrimą Lietuvos pavyzdžiu.

Darbo tikslui ţgyvendinti iškelti šie uždaviniai:

- išskirti ir apibūdinti elektros energijos rinkos kainos savybes;

- susisteminti veiksnius, darančius įtakos elektros energijos rinkos kainos savybių pasireiškimui;

- išskirti rodiklius, padedančius ịvertinti elektros energijos rinkos kainos savybes;

- ištirti Lietuvos elektros energijos rinkos kainos savybes.

Tyrimo metodai: mokslinès literatūros sisteminimas, statistinès analizès metodas.

Duomenu šaltinis. Elektros energijos rinkos kainos savybių analizei atlikti reikalingi duomenys paimti iš Lietuvos elektros energijos rinkos operatoriaus duomenų bazès.

Darbą sudaro kelios struktūrinès dalys. Antroje darbo dalyje susisteminta mokslinè literatūra ir pasaulio šaliu patirtis kainos savybių tyrimo problematika. Trečioje darbo dalyje išskirti rodikliai, leidžiantys ịvertinti pagrindines elektros energijos rinkos kainos savybes - kainos kaitumą ir kainos smailių susiformavimą. Ketvirtoje darbo dalyje pristatomi empirinio tyrimo rezultatai. Šioje darbo dalyje analizuojamos Lietuvos elektros energijos biržos kainos savybès ir veiksniai, darantys ịtaką savybių pasireiškimui.

\section{Mokslinès literatūros apžvalga}

Daugiau nei prieš du dešimtmečius prasidejjusi ir tebesitęsianti elektros energetikos sektoriaus pertvarka lèmé tai, kad elektros energija tapo preke (Shahidehpour et al. 2002; Weron, Misiorek 2008), kurią galima pirkti ir parduoti rinkos kainomis. Vis dèlto elektros energija yra labai specifinè prekè, kuriai būdinga:

- elektros energija yra homogeniné preke;

- ji nèra sandèliuojama ir privalo būti gaminama tuo metu, kai vartojama (Lucia, Schwartz 2002; Yu, Sheblé 2006; Karakatsani, Bunn 2008);

- elektros energijos persiuntimo galimybès, priklausančios nuo perdavimo tinklo charakteristikų, yra labai ribotos;

- elektros energijos paklausa yra išvestinè (Jamil, Ahmad 2011), nes prekè vartotojui būtina ne pati savaime, tačiau tiek, kiek ji leidžia tenkinti kitus jo poreikius;

- ilguoju ir trumpuoju laikotarpiais elektros energijos paklausa yra neelastinga kainos atžvilgiu (Lijesen 2007; Weron, Misiorek 2008; Fan, Hyndman 2011).

Išvardytos elektros energijos kaip prekès savybès lemia tai, kad prielaidų arbitražui yra mažai (Yu, Sheblé 2006) arba jis neįmanomas (Lucia, Schwartz 2000), kaina gali staigiai pakilti ir kristi, ji priklauso nuo vietos pasiūlos ir paklausos sąlygų (Lucia, Schwartz 2000).

Apibendrinus mokslinę literatūrą, galima išskirti ir kitas elektros energijos rinkos kainos savybes (Conejo et al. 2005; Knittel, Roberts 2005; Seifert, Uhrig-Homburg 2007; Swider, Weber 2007; Karakatsani, Bunn 2008):

- kainos formuojamos dažnai (angl. high frequency);

- vis dažniau pastebimos neigiamos elektros energijos kainos (angl. negative prices);

- kainai būdingas sezoniškumas ir kitas periodiškumas;

- po svyravimų elektros energijos kaina dažnai sugrįžta prie vidutinio lygio (angl. mean-reverting);

- kainai būdingas kaitumas (angl. price volatility);

- kainai būdingas šuoliškumas (angl. price jumps);

- formuojasi kainų smailès (angl. price spykes).

Toliau tekste išsamiau analizuojamos išvardytos elektros energijos rinkos kainos savybès.

Neatideliotina elektros energijos kaina formuojama dažnai. Kainos formavimo dažnumas priklauso nuo priimtų dalyvavimo elektros energijos rinkoje taisyklių. Lietuvos elektros energijos biržoje BaltPool, Skandinavijos šalių biržoje NordPool, Lenkijos - POLPX, Europos energijos biržoje - EEX ir daugelyje kitų biržų kainos formuojamos kiekvieną valandą, o Australijoje ir Naujojoje Zelandijoje - kas pusvalandị. Tokiu būdu per parą nusistovi 24 arba 48 kainos.

Elektros energijos kainos gali büti ne tik teigiamos, bet ir neigiamos. Iprasta, kad elektros energijos gamintojai teiktu 
pasiūlymus rinkai kaina, atitinkančia ribines jų gamybos sąnaudas. Išimtiniais atvejais elektros energijos gamintojai, siekdami išlikti rinkoje ir nenoredami stabdyti elektros energijos gamybos, gali nuspręsti tiekti elektros energiją mažesne kaina nei jų ribinès sąnaudos. Kraštutiniu atveju gamintojas gali teikti rinkai pasiūlymus, kuriuose fiksuojama, kad jis sutinka sumokèti už pagamintą ir patiektą elektros energiją. Dèl to rinkoje formuojama neigiama kaina. Ji reiškia, kad vartotojui nereikia mokèti už suvartotą elektros energiją. Atvirkščiai, kuo daugiau vartotojas suvartoja elektros energijos, tuo daugiau gamintojas jam sumoka.

Apibendrinus pasaulinę neigiamų kainų formavimosi patirtị, galima išskirti keletą neigiamų kainų formavimosi priežasčių. Viena vertus, neigiamos kainos susidaro, kai nèra elektros energijos paklausos, arba tada, kai ji labai maža. Maža elektros energijos paklausa formuojasi valstybinių švenčių dienomis, savaitgaliais, taip pat ekonomikos aktyvumo suletejiimo laikotarpiu, kai pramonès produkcijos paklausa, o dèl to ir elektros energijos, mažèja (Schneider, S., Schneider, S. 2010).

Kita vertus, neigiamas kainas gali suformuoti tradicinès elektros energijos gamintojai. Technologiniu požiūriu nelanksčioms elektrinèms (atominèms, anglị deginančioms elektrinèms arba gamtinių dujų garo turbinų atveju), negalinčioms greitai reaguoti i pokyčius rinkoje, yra ekonomiškai naudinga tomis valandomis, kai elektros energijos vartojimas yra mažas, siūlyti kuo mažesnes pardavimo kainas ir net sumoketi už elektros energiją, jei tik tos elektrinès darbo nereikès stabdyti. Tokiu būdu gamintojų patiriamos sąnaudos bus mažesnès už sąnaudas, kurios susidarytų, jei elektrinę tektų stabdyti, o už kelių valandų padidèjus paklausai vèl ją ijungti.

Pastaruosius keletą metų kai kurių pasaulio šalių rinkose (Pietų Australijoje, Vakarų Teksase, Vokietijoje, Šiaurès Europos šalyse) neigiamos elektros energijos kainos formuojasi dèl sparčios vèjo energetikos plètros. Vakarų Teksaso patirtis rodo, kad $2008 \mathrm{~m}$. pirmajji pusmetị daugiau nei 20 proc. viso laiko elektros energija rinkoje buvo prekiaujama neigiamomis kainomis. Kaip nurodo S. Schneider ir S. Schneider (2010), pagrindinès to priežastys - vèjo energijos dalies elektros energijos gamybos struktūroje augimas, menkas gyventojų tankumas regione, taip pat neišplètotas Vakarų Teksaso elektros tinklas su kaimyniniais regionais, kuris riboja perteklinio elektros energijos kiekio persiuntimą.

M. Giberson (2008) teigimu, neigiamos kainos rinkoje formuojasi dèl teikiamos paramos vèjo elektros energijai. Parama priklauso nuo pagaminto elektros energijos kiekio, todèl gamintojas nèra suinteresuotas tiekti mažiau elektros energijos. Kaip teigia M. Giberson (2008), jegainèms ekonomiškai naudinga gaminti tol, kol vejjo elektros energijos subsidijos dydis viršys elektrinių eksploatacinių sąnaudų ir neigiamos rinkos kainos sumą. Remdamasis rinkų stebejjimų rezultatais, M. Giberson (2008) padarè išvadą, kad
Vakarų Teksase vejjo jėgainių savininkams yra priimtinos visos kainos, jei jos nèra mažesnès nei minus 35 USD/MWh.

$2008 \mathrm{~m}$. Vokietijos biržoje EEX buvo leista formuotis neigiamoms kainoms. Jau 2008 m. spalio mèn. elektros energijos gamintojai mokejjo jos vartotojams 500,02 EUR/ MWh (Loon 2010). 2009 m. Skandinavijos šalių biržoje NordPool taip pat buvo leista kainoms igyti neigiamas reikšmes.

Neigiamos elektros energijos kainos vartotojams yra priimtinos, tačiau investuotojams jos signalizuoja apie mažejjantị pelningumą, todèl investicijų apimtys ị sektorių gali pradèti mažèti. Problemų atsiras tuomet, kai išaugus elektros energijos paklausai ir dèl nepalankių gamtiniu sąlygų vèjo elektrinėms negaminant elektros energijos, nebus galima tenkinti vartotojų poreikių arba vartotojus reikès aprūpinti labai brangia elektros energija. Taigi šiandien nemokamas elektros energijos tiekimas gali lemti ypač didelị ir teigiamą kainų šuolị rytoj.

Vienas iš būdų, padedančių mažinti neigiamų kainų formavimąsi, - stiprinti perdavimo tinklus. Sustiprinus perdavimo tinklą, galima būtų vejjo elektros energiją persiųsti i pramoninius regionus. Tačiau tam reikalingos investicijos. Kitas būdas - būtina kontinentinès prekybos elektros energija plètra. Integruojant elektros energijos rinkas laikinas elektros energijos perteklius galètų būti persiunčiamas ị kitus prasčiau elektros energija aprūpintus regionus.

Šiaurès Europos šalys neigiamų kainų problemą sprendžia tokiu būdu: Danijoje pagaminta perteklinè vejjo elektros energija siunčiama Norvegijai ir Švedijai. Šiose šalyse didelè dalis elektros energijos gaminama hidroelektrinèse, kuriose dalis elektros energijos suvartojama vandeniui $i$ rezervuarus pumpuoti. Pučiant stipriam vejui, Danijos jègainèse pagaminta elektros energija vartojama Norvegijoje ir Švedijoje. Nesant vejo, ijungiamos hidroelektrinès ir elektros energija gaminama jose. Labai neigiamų kainų formavimasis gali būti pristabdomas nustačius minimalias kainas (Loon 2010).

Viena labiausiai pastebimu elektros energijos kainu savybiu - jos kaitumas. Tyrimų rezultatai atskleidžia, kad elektros energijos kainos yra būtent tos kainos, kurioms būdingas ypač didelis kaitumas, kurio nèra ne tik kitų prekių, bet ir vertybiniu popieriu rinkose. JAV Federalinès energijos reguliavimo komisijos paskelbtoje ataskaitoje nurodoma, kad elektros kainos kaitumas JAV - 300 proc., kitų prekių rinkose šis rodiklis neviršijo 100 proc., o akcijų rinkoje svyravo apie 20 proc. arba buvo net mažesnis (Higgs, Worthington 2008). J. J. Lucia ir E. S. Schwartz (2002), išanalizavę Skandinavijos šalių biržos duomenis, nurodè, kad elektros kainos kaitumas, apskaičiuotas pagal standartinio kaitumo rodiklio formulę, buvo 189. Pastebèta, kad kainų kaitumas šiltu ir šaltu metų laiku gerokai skyrèsi. Kainos buvo stabilesnès šaltuoju metų laiku $(\sigma=54,2)$, jų kaitumas didejo šiltuoju sezonu $(\sigma=75,8)$. R. Booth skaičiavimų rezultatai rodo, kad Australijoje elektros energijos kainos 
kaitumas kaip nė vienoje kitoje pasaulio šalyje buvo ypač aukštas ir viršijo 900 proc. (Higgs, Worthington 2008). Vèlesniu laikotarpiu H. Higgs ir A. Worthington (2008) pakartojo kainų kaitumo tyrimą Australijoje. Tyrimų rezultatai patvirtina R. Booth išvadą ir atskleidžia, kad elektros energijos kainų kaitumas yra 14 kartų didesnis smailių formavimosi laikotarpiais nei iprastu laikotarpiu, kai rinka yra „rami“.

H. Bessembinder ir M. J. Lemmon (2002) tyrimų rezultatai atskleidžia, kad elektros energijos kainos kaitumas yra didesnis, kai yra didesnè elektros energijos paklausa.

Ch. R. Knittel ir M. R. Roberts (2005) nustate, kad elektros energijos kainos tampa kaitesnès, kai rinką ištinka kainų augimą sukeliantys šokai. Kainas mažinančių šokų itaka kainų kaitumui pastebèta nebuvo. Tokią situaciją mokslininkai pavadino atvirkštiniu sverto efektu (angl. inverse leverage effect).

Europos Komisijos užsakymu parengtoje ataskaitoje nurodoma, kad kainos kaitumą elektros energijos rinkose veikia šie veiksniai (The Moffatt Associates Partnership 2008):

- galių atjungimas (angl. capacity withdrawal);

- $\mathrm{CO}_{2}$ (anglies dvideginio) kainų svyravimai;

- tarpvalstybiniai tinklų perkrovimai (angl. corss-border congestion);

- anglies kainų svyravimai;

- nepastovi gamyba vèjo elektrinèse;

- manipuliavimas rinka;

- naftos kainų svyravimai;

- paklausos sezoniškumas.

Respondentų nuomone, dažniausiai elektros energijos kainos kaitumą sukelia galių atjungimas ir $\mathrm{CO}_{2}$ kainų svyravimai.

F. A. Wolak (1998) tyrimo rezultatai papildo Moffatt Associates Partnership (2008) tyrimo rezultatus. Apskaičiavęs Anglijos ir Velso, Skandinavijos šalių, Australijos ir Naujosios Zelandijos vidutines kainas, kainų standartinius nuokrypius ir variacijos koeficientus mokslininkas pagrindè, kad elektros energijos gamyboje naudojamų išteklių derinys gali paaiškinti vidutinị elektros energijos kainų lygị ir kainų kaitumą. Nustatyta, kad šalyse, kuriose elektros energijos gamyboje dominuoja iškastinis kuras (Australijoje, Anglijoje ir Velse), kainos yra mažiau kaičios nei šalyse (Skandinavijos šalyse ir Naujojoje Zelandijoje), kuriose plačiai naudojami vandens ištekliai. Tyrimų rezultatai leido suformuluoti išvadą, kad vandens išteklių lygis buvo pagrindinis kainų kaitumą paveikęs veiksnys Skandinavijos šalyse. Sausuoju metų laiku ir žiemą, kada vandens lygis rezervuaruose yra žemas, galimybès patiekti elektros energiją i rinką yra menkos, todèl elektros energijos kaina didejja ir tampa kaiti. Iškastinị kurą naudojantys gamintojai nèra tokie jautrūs oro sąlygų pokyčiams, tačiau jų sprendimus lemia iškastinio kuro kainos. Gerai integruotos anglies, gamtinių dujų ir naftos rinkos, kuriose kaina nagrinètu laikotarpiu mažai kito, prisidèjo prie elektros energijos kainos stabilumo. Tačiau dèl susiformavusio iškastinio kuro kainų vidutinio lygio, elektros energijos kainos iškastinị kurą naudojančiose šalyse yra didesnės už kainas tų šalių, kuriose gamyboje plačiau naudojami vandens ištekliai. Tyrimo metu nustatyti ir kiti kainos kaitumą veikiantys veiksniai. Palyginus rinkas nustatyta, kad:

- privalomo dalyvavimo elektros energijos rinkose kainos yra kaitesnès nei savanoriško dalyvavimo rinkose;

- elektros energijos rinkose, kuriose dominuoja privatus kapitalas, kainos yra kaitesnès, bet ir mažesnès nei tose rinkose, kuriose vyrauja valstybinis kapitalas. Nuosavybès teise valstybei priklausančios įmonès dažnai nepriima rizikingų sprendimų. Jų tikslas - užtikrinti stabilias pajamas. Privačios įmonès siekia pelno maksimizavimo tikslų.

Dar viena elektros energijos kainos savybė, kuri buvo pastebèta Australijoje, Šiaurès Kalifornijoje, - elektros energijos kainos svyravimas apie vidutini jos lygi. Irodymų, kad elektros energijos kaina turi šią savybę, rado Ch. Knittel ir M. R. Roberts (2005), R. Huisman et al. (2007), H. Higgs ir A. Worthington (2008).

Kainos svyravimas apie vidutinị lygi reiškia, kad po to, kai ịvyksta kainų šuolis arba susiformuoja kainų smailè, elektros energijos rinkos kaina turi ypatybę grižti ị ịprastą ir vyraujantị lygị. Taigi pasireiškusių kainos veiksnių itaka kainai yra laikina ir neiškreipia jos kitimo krypties bei lygio.

Elektros energijos kainai büdingi dèsningi svyravimai. Mokslininkai pastebi, kad elektros energijos kaina dèsningai kinta per parą ir atspindi visuomenès gyvenimo ritmą. Vienokia kaina būna anksti ryte, vèliau didejjant elektros energijos paklausai ji dideja, o pasibaigus darbo dienai ir paklausai pradèjus mažèti - mažèja (Knittel, Roberts 2005).

Kainos kitimo tendencijos skiriasi darbo dienomis ir savaitgaliais. Pastebèta, kad darbo dienomis kainos būna aukštesnès nei savaitgaliais. Paprastai anksti ryte ir vèlai vakare kainos sutampa. Atotrūkis tarp kainų formuojasi dieną (Knittel, Roberts 2005).

Elektros energijos kainos atspindi sezoniškumą, skirtingais metų laikais rodantị kintantị elektros energijos poreikį patalpoms šildyti ir vèdinti. Šiaurès Kalifornijos patirtis byloja, kad elektros energijos suvartojimo apimtys išauga vasarą, kai elektros energija vartojama patalpoms vèsinti. Šiuo sezonu kainos pikinio vartojimo metu gali keliskart viršyti elektros energijos kainas rudens laikotarpiu. Elektros energijos kainos dydį taip pat lemia ribojimai, susidarantys skirstymo ir perdavimo tinkluose. Esant gedimams, remontams ar kitiems ribojimams tinkluose, kai kurie regionai gali būti atskirti nuo visos rinkos. Tokiu atveju gamintojai pradeda naudotis susidariusia situacija rinkoje. Pastebeta, kad tokiu atveju elektros energijos kainos gali išaugti net keliasdešimt kartų. 
Be aptartų savybių elektros energijos kaina pasižymi šuolišku kitimu arba rinkoje gali susiformuoti vienkartinès kainu smailès. Atlikus mokslinès literatūros analizę, nustatyta, kad priežasčių kainų šuoliams ir smailèms formuotis yra daug. D. Caves et al. (2000), X. Lu et al. (2005), J. Seifert ir M. Uhrig-Homburg (2007) nurodo, kad trumpalaikès ir ilgalaikès kainų smailès formuojasi dèl tokių priežasčių:

- sustabdžius elektrinių darbą;

- esant gedimams tiekimo linijose;

- pasikeitus orų sąlygoms;

- dèl paklausos neelastingumo kainų atžvilgiu;

- vartotojų keliamos panikos rinkoje;

- prekiautojų isipareigojimų nevykdymo;

- gamintojų igyjamos galios rinkoje.

W. R. Hughes ir A. Parece (2002) pateikia išsamesni kainų smailių formavimosi veiksnių sąrašą. Visus veiksnius, lemiančius kainų smailių formavimąsi, jie skirsto ị tris grupes:

- veiksniai, lemiantys pasiūlos pokyčius;

- veiksniai, sukeliantys paklausos svyravimus;

- rinkos organizavimo ir rinkos struktūros veiksniai.

Mokslininkų (Hughes, Parece 2002) teigimu, staigius pasiūlos pokyčius lemia elektrinèse instaliuota galia ir sparčiai augantis galių naudojimo lygis, netikèti elektrinių sustabdymai, perdavimo tinklo ribojimai ir gamyboje naudojamų išteklių derinys. Netiketi paklausos svyravimai atsiranda pasikeitus oro sąlygoms, sumažèjus (padidejus) ekonominiam aktyvumui regione ir pasikeitus mažmeninėms elektros energijos kainoms. Kaip nurodo autoriai, mažmeninèms elektros energijos kainoms didejjant, vartotojai gali priimti sprendimą mažiau vartoti elektros energijos. Dèl to kainų smailių formavimosi tikimybè sumažèja. Rinkos organizavimas ir struktūra taip pat gali paaiškinti kainų smailių formavimosi procesą. Šiai veiksnių grupei autoriai priskiria mažmeninių ir didmeninių kainų kepurių ịtaką. Autorių nuomone, didmeninès elektros energijos kainos kepurès sudaro prielaidas kartotiniam kainų smailių (kainų šuolių) pasireiškimui. I̦vedus didmeninèms kainoms „kepures“, rinka gali prarasti jai svarbią informacija apie papildomų gamybinių galių poreikị ir tokiu būdu gali būti neišvengta energetinių krizių. H. Higgs ir A. Worthington (2008) apskaičiavo, kad Australijoje elektros energijos kainos smailių susiformavimo tikimybè per parą yra 5,16-9,44 proc. X. Lu et al. (2005) pažymi, kad kainų smailių tikimybè yra didelè elektros energijos pikinio vartojimo valandomis ir darbo dienomis, taip pat tais atvejais, kai yra didelè paklausa arba gamybos rezervinè galia yra mažesnè už tam tikrą lygi.

Aptarus elektros energijos kainos savybes, kitoje darbo dalyje pasiūlomi rodikliai, leidžiantys ịvertinti elektros energijos kainos kaitumo ir kainų smailių savybes.

\section{Elektros energijos kainos kaitumo ir kainos smailių vertinimo rodikliai}

Kainos kaitumo rodikliai. Dažniausiai mokslininkai išvadas apie elektros energijos kainos kaitumą daro išanalizavę kainos absoliutų ir santykinị pokyčius. Retesniais atvejais kainos kaitumui ịvertinti skaičiuojami tokie rodikliai:

- dispersija;

- standartinis nuokrypis;

- standartinis kaitumas;

- variacijos koeficientas;

- osciliacijos koeficientas.

S. Danilenko (2007) nurodo, kad kaitumui vertinti reikètų naudoti dispersijos rodiklị. Jis apskaičiuojamas pagal (1) formulę:

$$
\sigma^{2}=\frac{1}{n-1} \cdot \sum_{i=1}^{n}\left(x_{i}-\bar{x}\right)^{2}, \text { kai } \bar{x}=\frac{1}{n} \cdot \sum_{i=1}^{n} x_{i},
$$

čia $\sigma^{2}$ - dispersija; $n$-stebinių skaičius; $\bar{x}$ - laiko eilutès aritmetinis vidurkis.

Kuo didesnè dispersijos koeficiento reikšmè, tuo elektros energijos kaina yra kaitesnè.

F. A. Wolak (1998) kainos kaitumui įvertinti taikè standartinio nuokrypio formulę:

$$
\sigma=\sqrt{\sigma^{2}}
$$

J. J. Lucia ir E. S. Schwartz (2002) kaitumą matavo standartinio kaitumo rodikliu, kurị apskaičiavo pagal (3) formulę:

$$
V=\sigma \cdot \sqrt{365},
$$

čia $\sigma$ - vidutinis kvadratinis nuokrypis.

M. P. Muñoz ir D. A. Dickey (2009) elektros energijos kaitumą skaičiavo kaip laiko eilutės dviejų gretimų reikšmių skirtumo kvadratą:

$$
V=\left(Y_{t}-Y_{t-1}\right)^{2} .
$$

V. Bobinaitè et al. (2006), V. Bobinaitė (2011) elektros energijos kainos kaitumui vertinti taikè variacijos koeficientą:

$$
V=\frac{\sigma}{\bar{x}} \cdot 100
$$

čia $V$ - variacijos koeficientas; $\sigma$ - vidutinis kvadratinis nuokrypis; $\bar{x}$ - kainos aritmetinis vidurkis.

Variacijos koeficiento reikšmé vertinama taip (Bartosevičienè 2001):

- iki 10 proc. - variacija maža;

- nuo 10 proc. iki 20 proc. - variacija vidutiné;

- nuo 20 proc. iki 30 proc. variacija didele;;

- 30 proc. ir daugiau - variacija labai didelè. 
K. B. Paulavičius (2010) kaitumui matuoti pasiūlè taikyti osciliacijos koeficientą:

$$
K_{R}=\frac{x_{\max }-x_{\min }}{\bar{x}} \cdot 100,
$$

čia $x_{\max }$ - maksimali kintamojo reikšmé; $x_{\min }-$ minimali kintamojo reikšmè.

Taigi, atlikus mokslinès literatūros analizę, galima teigti, kad nèra vieno rodiklio kainos kaitumui vertinti. Neatsižvelgiant $\mathfrak{i}$ tai, kuris rodiklis taikomas kaitumui identifikuoti, šios elektros energijos rinkos kainos savybès atskleidimas teikia vertingą informaciją numatant kainos kitimo tendencijas ateityje. Nustačius, kad elektros energijos rinkos kaina yra kaiti, būtina pasirinkti tokius prognozavimo metodus ir modelius, kurie vertina kainos kaitumą ir leidžia padidinti kainos prognozių patikimumą.

Kainu smailių rodikliai. Elektros energijos rinkos kainu smailèms vertinti gali būti taikomi keli metodai (1 lentelè).

Dažniausiai kainų smailès nustatomos atsižvelgus i apskaičiuotas kainos kritines reikšmes. Laikoma, kad visos elektros energijos kainos, kurios yra didesnès arba mažesnès už apskaičiuotas kainos kritines reikšmes, atitinka kainų smailès apibrěžimą. Atsižvelgus ị elektros energijos kainos variacijos užmoji, kuris parodo, kokiame intervale kito kainos analizuojamu laikotarpiu, vidutinę elektros energijos kainą ir jos standartinį nuokrypị, kainos kritinès reikšmès gali būti apskaičiuojamos pritaikius $2 \cdot \sigma, 3 \cdot \sigma$ ar $4 \cdot \sigma$ taisyklę. Pastebejus, kad kai kurie elektros energijos kainos duomenys keliolika ar keliasdešimt kartų nukrypsta nuo vidutinio to laikotarpio lygio, vertètų kainų smailèmis laikyti visas reikšmes, kurios nuo vidurkio nukrypsta per 3 ar 4 standartinius nuokrypius.

Kainų smailemis taip pat laikomos visos neigiamos kainos, kurios parodo, kad gamintojas sutinka sumoketi vartotojui už jam patiektą elektros energiją. Kadangi šiuo metu ne visose elektros energijos rinkose kainoms leidžia- ma ịgyti neigiamas reikšmes, neigiamos kainų smailès ne visur pasireikš.

Remiantis išskirtais elektros energijos rinkos kainos kaitumo ir kainos smailių vertinimo rodikliais, toliau darbe atliekamas rodiklių taikomumo tyrimas Lietuvos sąlygomis.

\section{Biržos elektros energijos kainos savybių tyrimo rezultatai}

Nuo $2010 \mathrm{~m}$. sausio $1 \mathrm{~d}$. Lietuvoje pradëjo funkcionuoti elektros energijos birža. Ji ịvairiems rinkos dalyviams atvėré kelius prekybą vykdyti skaidrioje konkurencineje aplinkoje, kur kaina susiformuoja veikiama pasiūlos ir paklausos dėsnių. Baigiantis antriesiems prekybos biržoje metams, svarbu ịvertinti, kaip keitèsi, kodèl keitèsi ir kas buvo būdinga pagrindiniam rinkos parametrui - kainai. Pažinus elektros energijos kainos kitimo savybes ir kainų pokyčių priežastis, bus lengviau numatyti elektros energijos kainos kitimo tendencijas ateityje. Kainos kitimo dèsningumų pažinimas palengvins sprendimų prièmimą ateityje ir padès rinkos dalyviams pasiekti užsibrèžtu tikslų.

Šiame darbe biržos elektros energijos kainos savybès analizuojamos pasirinkus $2010 \mathrm{~m}$. sausio mèn. - $2011 \mathrm{~m}$. rugsèjo mèn. kasdienius valandinius duomenis. Siekiant atskleisti elektros energijos kainos kaitumo ir kainos smailių savybes, laikotarpis buvo suskirstytas ị trumpesnès trukmès laiko tarpus. Jie atitinka kalendorinius metų laikus. Skaičiavimai atliekami remiantis informacija, pateikta 1 pav. Kaip matyti, 2009 m. gruodžio pabaigoje uždarius VIt Ignalinos atominès elektrinès antrąji bloką, elektros energijos rinkos kaina išaugo du kartus nuo 82,94 LTL/ MWh 2005-2009 m. iki 159,86 LTL/MWh. Kainos augimą lèmè tai, kad dali Ignalinos AE gamintą elektros energijos kiekị rinkai pradejjo siūlyti $\mathrm{AB}$ „Lietuvos elektrinë“, kurios pagrindinis kuras - gamtinès dujos. $2010 \mathrm{~m}$. duomenimis, elektros energijos gamybos apimtys $\mathrm{AB}$,Lietuvos elektrinë“

1 lentelè. Elektros energijos rinkos kainos smailių identifikavimo rodikliai

Table 1. Indicators identifying spikes of power market price

\begin{tabular}{|c|c|c|c|}
\hline Autorius & Rodiklis & $\begin{array}{l}\text { Rodiklio } \\
\text { skaičiavimo formulè }\end{array}$ & Rodiklio reikšmės vertinimas \\
\hline \multirow[t]{2}{*}{ X. Lu et al. (2011) } & $\begin{array}{l}\text { Kritinè } \\
\text { kainos } \\
\text { reikšmè }\end{array}$ & $P_{K}=\bar{x} \pm 2 \cdot \sigma$ & $\begin{array}{l}\text { Jei } P>P K \text {, kai } P_{K}=\bar{x}+2 \cdot \sigma \text {, arba } P<P K \text {, kai } P_{K}=\bar{x}-2 \cdot \sigma \text {, } \\
\text { tai } P \text { atitinka kainų smailès apibrěžimą. Kainos kritinèms } \\
\text { reikšmèms nustatyti gali būti taikoma } 3 \cdot \sigma, 4 \cdot \sigma .\end{array}$ \\
\hline & $\begin{array}{l}\text { Neigiama } \\
\text { kaina }\end{array}$ & $P<0$ & $\begin{array}{l}\text { Neigiama rinkos kainos reikšmė atitinka kainų smailès } \\
\text { apibréžimą. }\end{array}$ \\
\hline $\begin{array}{l}\text { J. J. Lucia ir } \\
\text { E. S. Schwartz } \\
(2002)\end{array}$ & $\begin{array}{l}\text { Asimetrijos } \\
\text { koeficientas }\end{array}$ & $A_{S}=\frac{\mu_{3}}{\sigma^{3}}$ & $\begin{array}{l}\text { Jei } A_{s}>0 \text {, kaina kraštutinai dideles reikšmes igyja dažniau nei } \\
\text { kraštutinai mažas. }\end{array}$ \\
\hline
\end{tabular}

čia $\sigma$-standartinis nuokrypis, $\bar{x}$ - laiko eilutès aritmetinis vidurkis, $\mu_{3}$ - centrinis trečios eilès momentas. 
išaugo daugiau nei du kartus ir sudarè 2,02 TWh. Vertètų pažymèti ir tai, kad įtakos vidutinès kainos pokyčiams turèjo importuoto elektros energijos kiekio pokyčiai. $2010 \mathrm{~m}$. elektros energijos importo apimtys padidèjo daugiau nei 10 kartų ir siekè 7,13 TWh.

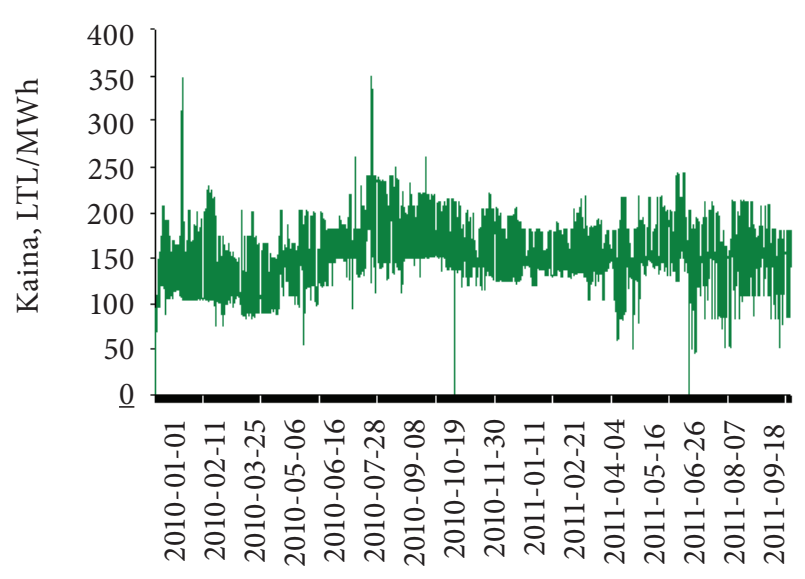

1 pav. Elektros energijos kainos biržoje kitimo tendencijos 2010 m. (BaltPool 2010, 2011)

Fig. 1. Development of power price in the stock exchange in 2010 (BaltPool 2010, 2011)

1 pav. pateikta informacija taip pat rodo, kad kaina biržoje yra kaiti. Apskaičiuotas analizuojamo laikotarpio standartinio nuokrypio koeficientas - 33,33 LTL/MWh. Jis rodo elektros energijos kainos pasklidimą apie vidutinįlaikotarpio lygi. Apskaičiavus variacijos užmojo koeficientą nustatyta, kad skirtumas tarp maksimalios ir minimalios laikotarpio reikšmès buvo 350,01 LTL/MWh. Tai atspindi, kad kainos kitimo intervalas buvo platus. Variacijos koeficiento reikšmè $(20,85$ proc.) atskleidžia, kad kainos kaitumas buvo didelis. 2 lenteleje pateikti kaitumo rodikliai, analizuojamą laikotarpi suskirsčius ị sezonus. Kaip matyti, elektros energijos kaina kaičiausia buvo prekybos elektros energija biržoje pradžioje (variacijos koeficientas - 24,96 proc.). Pirmosiomis prekybos biržoje valandomis prekybos igūdžių dar neigiję gamintojai elektros energiją rinkai tiekè nemokamai. $2010 \mathrm{~m}$. sausio $27-28$ d. lauko oro temperatūrai nukritus žemiau $-20^{\circ} \mathrm{C}$, o šiluminių elektrinių valdytojams priemus sprendimus didinti šilumos gamybą, elektros energijos pasiūla biržoje sumažèjo ir lèmè elektros energijos kainos padidèjimą iki 345,25 LTL/MWh (BaltPool 2010). Palyginus elektros energijos kainos kitimo tendencijas pirmaisiais $2010 \mathrm{~m}$. ir $2011 \mathrm{~m}$. mènesiais, galima pastebèti, kad $2011 \mathrm{~m}$. elektros energijos kainos biržoje kitimo intervalas buvo itin siauras (variacijos užmojis 100,75 LTL/MWh), o elektros energijos kainos kaitumas - mažas (variacijos koeficientas 14,02 proc.). Vis dèlto vidutine elektros energijos kaina $2011 \mathrm{~m}$. sausio-vasario mèn. buvo aukštesnè, palyginti su kainomis $2010 \mathrm{~m}$.

Pavasario laikotarpiu elektros energijos kaina biržoje turi tendenciją mažèti. Tam ịtakos turi klimatiniai veiksniai. 2010 m. kovo-gegužès mèn. elektros energijos kaina biržoje sumažèjo 8,7 proc., palyginti su kainomis žiemos

2 lentelè. Elektros energijos rinkos kainos kaitumo rodikliai 2010-2011 m. (sudaryta autorių)

Table 2. Volatility indicators of power price in 2010-2011 (authors' calculations)

\begin{tabular}{|c|c|c|c|c|c|c|c|c|}
\hline \multicolumn{2}{|c|}{ Laikotarpis } & $\begin{array}{l}\text { Vidutinè } \\
\text { kaina, } \\
\text { LTL/ } \\
\text { MWh }\end{array}$ & $\begin{array}{l}\text { Minimali } \\
\text { kaina, } \\
\text { LTL/MWh }\end{array}$ & $\begin{array}{c}\text { Maksimali } \\
\text { kaina, } \\
\text { LTL/MWh }\end{array}$ & $\begin{array}{l}\text { Variacijos } \\
\text { užmojis, } \\
\text { LTL/MWh }\end{array}$ & $\begin{array}{l}\text { Osciliacijos } \\
\text { koeficientas, } \\
\text { proc. }\end{array}$ & $\begin{array}{l}\text { Standartinis } \\
\text { nuokrypis, } \\
\text { LTL/MWh }\end{array}$ & $\begin{array}{c}\text { Variacijos } \\
\text { koeficientas, } \\
\text { proc. }\end{array}$ \\
\hline \multirow{4}{*}{$2010 \mathrm{~m}$} & $\begin{array}{l}\text { sausis- } \\
\text { vasaris }\end{array}$ & 148,32 & 0,00 & 345,25 & 345,25 & 232,77 & 37,02 & 24,96 \\
\hline & $\begin{array}{l}\text { kovas- } \\
\text { geguže }\end{array}$ & 135,38 & 55,11 & 200,68 & 145,57 & 107,52 & 29,57 & 21,84 \\
\hline & $\begin{array}{l}\text { birželis- } \\
\text { rugpjūtis }\end{array}$ & 177,02 & 93,74 & 350,01 & 256,27 & 144,77 & 37,22 & 21,03 \\
\hline & $\begin{array}{l}\text { rugsèjis- } \\
\text { lapkritis }\end{array}$ & 174,61 & 0,10 & 260,03 & 259,93 & 148,86 & 28,07 & 16,08 \\
\hline \multirow{4}{*}{$2011 \mathrm{~m}$. } & $\begin{array}{l}\text { gruodis- } \\
\text { vasaris }\end{array}$ & 158,99 & 119,95 & 220,70 & 100,75 & 63,37 & 22,29 & 14,02 \\
\hline & $\begin{array}{l}\text { kovas- } \\
\text { gegužè }\end{array}$ & 158,27 & 52,10 & 217,60 & 165,50 & 104,57 & 28,59 & 18,07 \\
\hline & $\begin{array}{l}\text { birželis- } \\
\text { rugpjūtis }\end{array}$ & 164,60 & 0,28 & 241,90 & 241,62 & 146,80 & 32,50 & 19,74 \\
\hline & rugsèjis & 153,22 & 50,79 & 209,90 & 159,11 & 103,85 & 24,33 & 15,88 \\
\hline
\end{tabular}


metu. 2010 m. pavasarį reikšmingą itaką elektros energijos kainai darè Latvijos hidroelektrinèse pavasarinių potvynių metu pagaminta ir ị Lietuvą importuota elektros energija. Ji sumažino elektros energijos kainą Lietuvos biržoje $2010 \mathrm{~m}$. kovo-balandžio mèn. iki 127,5 LTL/MWh. 2011 m. pavasari polaidis Latvijoje buvo trumpas ir nedidelis, todè galimybiu gauti pigios Latvijos hidroelektrinèse pagamintos elektros energijos nebuvo (BaltPool 2011).

Dèl to $2011 \mathrm{~m}$. pavasarị vidutinè elektros energijos kaina biržoje padidejo 22,89 LTL/MWh, palyginti su kainomis, kurios vyravo atitinkamu laikotarpiu $2010 \mathrm{~m}$. Verta pažymèti ir tai, kad 2010 m. pavasarị atidarius biržą Estijoje keletas rinkos dalyvių nebeprekiavo Lietuvos biržoje. Tai galèjo sukelti tiek elektros energijos pasiūlos, tiek jos paklausos svyravimus ir lemti kainos pokyčius.

Vasaros laikotarpiui būdinga tai, kad:

- Lietuvoje elektros energijos beveik nebegamina šiluminès elektrinès, todèl ir neteikia elektros energijos pardavimo pasiūlymų;

- Latvijoje pasibaigus polaidžiams sumažeja hidroelektrinèse pagaminamos elektros energijos kiekis, todèl ir jos pasiūla Lietuvos rinkai;

- vasarą vyksta elektros perdavimo linijų planiniai remontai. Tai mažina galimybes iš gretimų energetikos sistemų persiųsti pigesnę elektros energiją i Lietuvą;

- dideja elektros energijos paklausa vésumos poreikiams, kurių susiformavimui įtakos turi aukšta vidutiné paros oro temperatūra (BaltPool 2010).

Dèl visų šių veiksnių pasireiškimo elektros energijos kaina vasaros metu paprastai viršija kainą, susiformuojančią šaltuoju metu laiku. Be to, kainos kaitumas vasaros laikotarpiui taip pat padidèja.

Prasidèjus šildymo sezonui ir šiluminèms elektrinèms sugrižus ị rinką, elektros energijos pasiūla didèja, elektros energijos kaina ir jos kaitumas mažèja. Pavyzdžiui, 2010 m. rudens laikotarpiu šiluminių elektrinių dalyvavimas Lietuvos rinkoje lèmè tai, kad maksimali kaina sumažèjo daugiau nei ketvirtadaliu iki 260,03 LTL/MWh, o kainos kaitumas - 5 procentiniais punktais (nuo 21,03 proc. iki 16,08 proc.).

Be aptartos kaitumo savybès, elektros energijos biržos kainai būdingas šuoliškas kitimas ir smailès. Šioms kainų savybėms ịvertinti skaičiuojami kainos kritinès reikšmès rodikliai. Remiantis rodiklių reikšmėmis skaičiuojamos tikimybès, leidžiančios ịvertinti, kiek valandų per metus reiškiasi kainų smailès. Skaičiavimo rezultatai pateikti 3 lentelèje.

Remiantis prielaida, kad kainų smailès - tai tos valandos, kai kaina biržoje didesné už 226,53 LTL/MWh arba mažesnè už 93,20 LTL/MWh (t. y. ivertinus du standartinius nuokrypius nuo vidurkio), apskaičiuota, kad kainų smailès Lietuvos biržoje formavosi 4,68 proc. viso 2010-2011 m. rugsèjo mèn. laiko.
Kaip matyti iš 3 lentelèje pateiktos informacijos, dažniausiai kainų smailès reiškèsi vasarą. Apskaičiuota, kad kainų smailès vasarą truko 2,64 proc. laiko. Pavasari kainų smailés sudare 1,52 proc., rudens - 0,33 proc., o žiemos - tik 0,18 proc. laiko. Skaičiavimų rezultatai rodo, kad ypač aukštos ir žemos kainos (įvertinus tris standartinius nuokrypius nuo vidurkio) Lietuvos biržoje vyravo 0,4 proc. laiko. Jos taip pat vyravo vasarą.

Kadangi ịvairiems metų laikams būdingos skirtingos vidutinès elektros energijos kainos ir jų kaitumas, nenuostabu, kad kritinès kainų reikšmès ịvairiais metų laikais taip pat nèra vienodos (3 lentelè). Pavyzdžiui, $2010 \mathrm{~m}$. pavasarị kainų smailèmis buvo galima vadinti kainas, viršijančias 194,52 LTL/MWh, arba mažesnes už 76,25 LTL/MWh. Tų pačių metų vasarą, padidejjus vidutinei elektros energijos kainai biržoje ir jos standartiniam nuokrypiui, apatinis rěžis padidejjo iki 102,57 LTL/MWh, o viršutinis - iki 251,47 LTL/ MWh. Taigi per metus, keičiantis vidutinei elektros energijos kainai ir jos kaitumui, keičiasi ir kainų smailių samprata. Pažymètina, kad kainų smailių pasireiškimo trukmé Lietuvos biržoje ilgejja. 2010 m. pavasarị kainų smailès pasireikšdavo 3,72 proc. kalendorinio pavasario laiko, o $2011 \mathrm{~m}$. atitinkamu laikotarpiu kainų smailès truko 6,21 proc. laiko.

Darbe taip pat buvo skaičiuojamas asimetrijos koeficientas. Jis parodè, kad Lietuvos biržoje kraštutinai didelès elektros energijos kainos reiškiasi dažniau nei kraštutinai mažos. Asimetrijos koeficiento reikšmé - 0,078.

\section{Išvados}

Konkurencinès didmeninès elektros energijos rinkos sukūrimas lèmè tai, kad elektros energijos kainos igijo visiškai naujų savybių. Susisteminus mokslinę literatūrą ir pasaulinę elektros energijos kainos savybių reiškimosi patirtị, išskirtos tokios elektros energijos rinkos kainos savybès: elektros energijos kainos formuojasi dažnai ir keičiasi atsižvelgiant i pasiūlos bei paklausos veiksnių pokyčius; elektros energijos kainos gali igyti ne tik teigiamas, bet ir neigiamas reikšmes; kainai būdingas sezoniškumas ir kitas periodiškumas; po svyravimų kainos sugrįžta prie vidutinio lygio; kainos yra kaičios; joms būdingas šuoliškas kitimas; dažnai formuojasi kainų smailès.

Teoriniu lygmeniu atlikus elektros energijos kainos savybių formavimosi priežasčiu analizę, galima teigti, kad elektros energijos kainos savybès pasireiškimas (nepasireiškimas) priklauso nuo to, kaip kainą paveikia veiksniai, darantys ịtaką elektros energijos pasiūlai ir paklausai. Taigi visus veiksnius, veikiančius elektros energijos kainos savybių pasireiškimą, galima sugrupuoti pagal veiksnių sąryšį su rinkos paklausa, pasiūla ir rinkos struktūra. Elektros energijos kaip prekès savybès taip pat veikia elektros energijos kainą ir jos savybių formavimąsi. 
3 lentelè. Elektros energijos kainos smailių vertinimo rezultatai (sudaryta autorių)

Table 3. Results of valuation of power price spikes (authors' calculations)

\begin{tabular}{|c|c|c|c|c|c|c|c|}
\hline \multirow{2}{*}{\multicolumn{2}{|c|}{ Laikotarpis }} & \multicolumn{2}{|c|}{$P_{K}=\bar{x} \pm 2 \cdot \sigma$} & \multirow{2}{*}{$\begin{array}{l}\text { Kainų smailès } \\
\text { tikimybė, kai } \\
\text { galioja } 2 \cdot \sigma \\
\text { taisyklè, proc. }\end{array}$} & \multicolumn{2}{|c|}{$P_{K}=\bar{x} \pm 3 \cdot \sigma$} & \multirow{2}{*}{$\begin{array}{l}\text { Kainų smailès } \\
\text { tikimybè, kai } \\
\text { galioja } 3 \cdot \sigma \\
\text { taisyklè, proc. }\end{array}$} \\
\hline & & $\begin{array}{l}\text { apatinis } \\
\text { réžis }\end{array}$ & $\begin{array}{l}\text { viršutinis } \\
\text { rèžis }\end{array}$ & & $\begin{array}{l}\text { apatinis } \\
\text { réžis }\end{array}$ & $\begin{array}{l}\text { viršutinis } \\
\text { rèžis }\end{array}$ & \\
\hline \multicolumn{2}{|c|}{$\begin{array}{l}2010-2011 \mathrm{~m} . \\
\text { sausis-rugsèjis: }\end{array}$} & \multirow{5}{*}{93,20} & \multirow{5}{*}{226,53} & 4,68 & \multirow{5}{*}{59,87} & \multirow{5}{*}{259,86} & 0,40 \\
\hline pavasaris & & & & 1,52 & & & 0,05 \\
\hline vasara & & & & 2,64 & & & 0,25 \\
\hline ruduo & & & & 0,33 & & & 0,03 \\
\hline žiema & & & & 0,18 & & & 0,08 \\
\hline \multirow{4}{*}{$2010 \mathrm{~m}$} & $\begin{array}{l}\text { sausis- } \\
\text { vasaris }\end{array}$ & 74,29 & 222,36 & 2,54 & 37,27 & 259,38 & 2,05 \\
\hline & $\begin{array}{l}\text { kovas- } \\
\text { gegužè }\end{array}$ & 76,25 & 194,52 & 3,72 & 46,68 & 224,09 & 0,00 \\
\hline & $\begin{array}{l}\text { birželis- } \\
\text { rugpjūtis }\end{array}$ & 102,57 & 251,47 & 1,81 & 65,35 & 288,69 & 1,04 \\
\hline & $\begin{array}{l}\text { rugsėjis- } \\
\text { lapkritis }\end{array}$ & 118,47 & 230,75 & 1,56 & 90,40 & 258,82 & 0,23 \\
\hline \multirow{4}{*}{$2011 \mathrm{~m}$} & $\begin{array}{l}\text { gruodis- } \\
\text { vasaris }\end{array}$ & 114,41 & 203,57 & 4,54 & 92,12 & 225,87 & 0,00 \\
\hline & $\begin{array}{l}\text { kovas- } \\
\text { gegužè }\end{array}$ & 101,08 & 215,46 & 6,21 & 72,48 & 244,05 & 0,68 \\
\hline & $\begin{array}{l}\text { birželis- } \\
\text { rugpjūtis }\end{array}$ & 99,61 & 229,59 & 5,34 & 67,11 & 262,08 & 1,18 \\
\hline & rugsèjis & 104,56 & 201,87 & 6,11 & 80,23 & 226,20 & 0,42 \\
\hline
\end{tabular}

Apibendrinus mokslinę literatūrą rinkos savybių vertinimo rodiklių problematika, nustatyta, kad elektros energijos rinkos kainų savybėms įvertinti gali būti taikomi ìvairūs rodikliai. Išvadas apie elektros energijos kainos kaitumą galima daryti išanalizavus kainos absoliutų ir santykinị pokyčius. Retesniais atvejais kainos kaitumui ịvertinti skaičiuojami tokie rodikliai, kaip dispersija, standartinis nuokrypis, standartinis kaitumas, variacijos koeficientas, osciliacijos koeficientas. Kainų smailèms identifikuoti rekomenduojama nustatyti kritines kainų reikšmes. Jos apskaičiuojamos įvertinus analizuojamo laikotarpio vidutinị kainos lygị ir jos standartinị nuokrypị.

Atlikus elektros energijos biržos kainos kaitumo tyrimą nustatyta, kad biržos elektros energijos kaina yra kaiti. Skirtingais metų laikais kainų kaitumas yra nevienodas. Žiemos laikotarpiu, kai prekybą rinkoje vykdo šiluminès elektrinès, kainos kaitumas mažèja, tačiau vidutinis kainų lygis kyla. Pavasarị, esant galimybei importuoti elektros energiją pigiau, kainos kaitumas didèja, o vidutinis kainų lygis mažèja. Kaičiausia ir didžiausia kaina būna vasarą. Šiuo metu laiku dažniausiai susiformuoja kainų smailès. Skaičiavimų rezultatai rodo, kad kainų smailès vasarą truko 2,64 \% viso 2010-2011 m. rugsejjo mèn. laiko, t. y. vasarą susiformuoja daugiau nei pusė visų kainų smailių.
Tyrimą finansavo (finansuoja) Lietuvos mokslo taryba (sutarties Nr. ATE-01/2011). Tyrimas buvo igyvendintas autorèms bendradarbiaujant su Kauno technologijos universitetu.

\section{Literatūra}

BaltPool 2010 duomenų bazè [interaktyvus], [žiūrèta $2011 \mathrm{~m}$. spalio 1 d.]. Prieiga per internetą: www.baltpool.lt

BaltPool 2011 duomenų bazè [interaktyvus], [žiūrèta $2011 \mathrm{~m}$. spalio 1 d.]. Prieiga per internetą: www.baltpool.lt

Bartosevičienè, V. 2001. Ekonominè statistika: mokomoji knyga. Kaunas: Technologija.

Bessembinder, H.; Lemmon, M. J. 2002. Equilibrium pricing and optimal hedging in electricity forward markets, The Journal of Finance 57(3): 1347-1382.

http://dx.doi.org/10.1111/1540-6261.00463

Bobinaite, V. 2011. Day-ahead electricity price forecasting: Lithuanian case, in Proceedings of the 6th International Conference on Electrical and Control Technologies. Kaunas: Technologija, 169-174.

Bobinaitè, V.; Juozapavičienè, A.; Snieška, V. 2006. Correlation of electricity prices in European wholesale power markets, Engineering Economics 4(49): 7-14. 
Caves, D.; Eakin, K.; Faraqui, A. 2000. Mitigating price spikes in wholesale markets through market-based pricing in retail markets, The Electricity Journal 13(3): 13-23. http://dx.doi.org/10.1016/S1040-6190(00)00092-0

Conejo, A. J.; Contreras, J.; Espínola, R.; Plazas, M. A. 2005. Forecasting electricity prices for a day-ahead pool-based electric energy market, International Journal of Forecasting 21(3): 435-462. http://dx.doi.org/10.1016/j.ijforecast.2004.12.005

Danilenko, S. 2007. Matematinių modelių taikymas akcijų rinkos analizeje, Liet. matem. rink., spec. 47: 442-447.

Elektros energetikos sistemos pokytis $2010 \mathrm{~m}$. ir planas iki 2015 m., Elektros rinka 2010: Naujienlaiškis Nr. 2.

Fan, S.; Hyndman, R. J. 2011. The price elasticity of electricity demand in South Australia, Energy Policy 39(6): 3709-3719. http://dx.doi.org/10.1016/j.enpol.2011.03.080

Giberson, M. 2008. Frequent Negative Power Prices in the West Region of ERCOT Result from Wasteful Renewable Power Subsidies [interaktyvus], [žiūrèta 2011 m. rugpjūčio 19 d.]. Prieiga per internetą:

http://knowledgeproblem.com/-2008/11/20/frequent_negati/

Higgs, H.; Worthington, A. 2008. Stochastic price modeling of high volatility, mean-reverting, spike-prone commodities: the Australian wholesale spot electricity market, Energy Economics 30: 3172-3285. http://dx.doi.org/10.1016/j.eneco.2008.04.006

Hughes, W. R.; Parece, A. 2002. The economics of price spikes in deregulated power markets, The Electricity Journal 15: 31-44. http://dx.doi.org/10.1016/S1040-6190(02)00329-9

Huisman, R.; Huurman, Ch.; Mahieu, R. 2007. Hourly electricity prices in day-ahead markets, Energy Economics 29(2): 240-248. http://dx.doi.org/10.1016/j.eneco.2006.08.005

Yu, W.; Sheblé, G. B. 2006. Modeling electricity markets with hidden Markov model, Electric Power Systems Research 76(67): 445-451. http://dx.doi.org/10.1016/j.epsr.2005.09.013

Jamil, F.; Ahmad, E. 2011. Income and price elasticities of electricity demand: aggregate and sector-wise analyses, Energy Policy 39(9): 5519-5527. http://dx.doi.org/10.1016/j.enpol.2011.05.010

Karakatsani, N. V.; Bunn, D. W. 2008. Forecasting electricity prices: the impact of fundamentals and time-varying coefficients, International Journal of Forecasting 24: 764-785. http://dx.doi.org/10.1016/j.ijforecast.2008.09.008

Knittel, Ch. R.; Roberts, M. R. 2005. An empirical examination of restructured electricity prices, Energy Economics 27: 791-817. http://dx.doi.org/10.1016/j.eneco.2004.11.005

Lijesen, M. G. 2007. The real-time price elasticity of electricity, Energy Economics 29(2): 249-258. http://dx.doi.org/10.1016/j.eneco.2006.08.008

Loon, J. 2010. Windmill Boom Cuts Electricity Prices in Europe [interaktyvus], [žiūrèta 2011 m. rugpjūčio 20 d.]. Prieiga per internetą: http://www.bloomberg.com/news/2010-04-22/ windmill-boom-curbs-electric-power-prices.html

Lu, X.; Dong, Z. Y.; Li, X. 2005. Electricity market price spike forecast with data mining techniques, Electric Power Systems Research 73(1): 19-29.

Lucia, J. J.; Schwartz, E. S. 2002. Electricity prices and power derivatives: evidence from the Nordic power Exchange, Review of the Derivatives Research 5(1): 1-50. http://dx.doi.org/10.1023/A:1013846631785

Muñoz, M. P.; Dickey, D. A. 2009. Are electricity prices affected by the US dollar to Euro exchange rate? The Spanish case, Energy Economics 31(6): 857-866. http://dx.doi.org/10.1016/j.eneco.2009.05.011

Nagayama, H. 2007. Effects of regulatory reforms in the electricity supply industry on electricity prices in developing countries, Energy Policy 35(6): 3440-3462.

http://dx.doi.org/10.1016/j.enpol.2006.12.018

Paulavičius, K. B. 2010. Taikomosios statistikos juvadas. Vilnius: Vilniaus pedagoginio universiteto leidykla. ISBN 978-995520-582-1.

Schneider, S.; Schneider, S. 2010. Power Spot Price Models with Negative Prices. MPRA Paper No. 29958 [interaktyvus], [žiūrèta $2011 \mathrm{~m}$. rugpjūčio 20 d.]. Prieiga per internetą: http://mpra.ub.uni-muenchen.de/29958/1/MPRA_paper_29958.pdf

Seifert, J.; Uhrig-Homburg, M. 2007. Modelling jumps in electricity prices: theory and empirical evidence, Rev. Deriv. Res 10: 59-85. http://dx.doi.org/10.1007/s11147-007-9011-9

Shahidehpour, M.; Yamin, H.; Li, Z. 2002. Market Operations in Electric Power Systems: Forecasting, Scheduling, and Risk Management. A John \& Sons, Inc. http://dx.doi.org/10.1002/047122412X

Swider, D. J.; Weber, Ch. 2007. Extended ARMA models for estimating price developments on day-ahead electricity markets, Electric Power Systems Research 77(5-6): 583-593. http://dx.doi.org/10.1016/j.epsr.2006.05.013

The Moffatt Associates Partnership 2008. Review and Analysis of EU Wholesale Energy Markets: Evaluation of Factors Impacting on Current and Future Market Liquidity and Efficiency [interaktyvus], [žiūrèta $2011 \mathrm{~m}$. rugpjūčio 16 d.]. Prieiga per internetą: http://ec.europa.eu/energy/gas_electricity/studies/doc/2008_eu_wholesale_energy_market_evaluation.pdf

Weron, R.; Misiorek, A. 2008. Forecasting spot electricity prices: a comparison of parametric and semiparametric time series models, International Journal of Forecasting 24: 744-763. http://dx.doi.org/10.1016/j.ijforecast.2008.08.004

Wolak, F. A. 1998. Market design and price behavior in restructured electricity markets: an international comparison, in Pricing in Competitive Electricity Markets. Kluwer Academic Publishers, 127-149.

Viktorija BOBINAITE். Junior research associate of Laboratory of Energy Systems Research at Lithuanian Energy Institute. Research interests: electricity price forecasting, energy policy, wider utilization of renewable energy sources.

Aldona JUOZAPAVIČIENĖ. Associate Professor of Department of Economics and International Trade. Faculty of Economics and Management, Kaunas University of Technology. Research interests: international financial markets. 